\title{
Internal Migration in Finland in 1977-78. A Survey Investigating the Reasons for Migration'
}

\author{
MAURI NIEMINEN \\ Planning Officer \\ Central Statistical Office
}

Population development has been characterized in the past few decades by 1) a strong decline in fertility and 2) changes caused by migration in the regional distribution of the population. Of these two factors, however, migration has more noticeably affected societal development. Economic growth has been accompanied by a change in the industrial structure, which has depopulated the rural areas and brought people into industrial and service occupations. ${ }^{2}$ In 1950 over $40 \%$ still earned their living from agriculture, but by 1980 the proportion formed by the agricultural population had dropped to around $10 \%$.

Regionally, migration has mainly been directed to Southern Finland. In part, this is because the majority of new jobs have been established in the provinces of Southern Finland. In Southern Finland, again, especially the capital and the surrounding municipalities have received the major portion of the migration gain.

The entrance of the large age classes - the baby boom of $1946-50$ - into the labor market had its share in increasing migration, especially in the beginning of the 1970s. Migration welled out partly as internal migration and partly as external migration. Not until the mid-1970s did any marked changes in migration begin to occur in relation to that of previous years. The annual migrant totals declined and a noticeable regional balance emerged, so that Southern Finland's pull weakened. At the end of the 1970s, especially, it could clearly be seen that migration gains and losses had decreased in almost all provinces compared to previous annual figures. ${ }^{3}$

When both migration within a municipality and migration between municipalities are included in internal migration, almost 600000 persons migrate annually, which equals about $12 \%$ of the population. One-third of the migrants are part of the migration between municipalities and the rest are migrants within a municipality. In the following, however, we will only examine migration between municipalities.

1 This article is based on a study published by the Central Statistical Office: Mauri Nieminen, Maassamuuton syyt 1977-78, Studies No. 82, Central Statistical Office, Helsinki 1982.

2 Nieminen, Mauri: Kaupunkiseudun muuttoliikkeen uudet piirteet, Siirtolaisuustutkimuksia A 8 ss. 97-107, Turku 1982.

${ }^{3}$ Nieminen, Mauri: Suomen muuttoliike tilastojen valossa, Siirtolaisuus-Migration Nro 1/1979. 
T a b l e 1. Internal migration in 1951-1980.

$\begin{array}{ccc}\text { Year } & \begin{array}{c}\text { Average annual } \\ \text { migration rate }\end{array} & \% \\ 1951-55 & 160400 & 38.7 \\ 1956-60 & 183800 & 42.1 \\ 1961-62 & 216400 & 47.9 \\ 1966-70 & 222300 & 48.2 \\ 1971-75 & 236700 & 51.8 \\ 1976-80 & 193600 & 40.7\end{array}$

As shown in Table 1, the average numbers of migrants were lowest in the beginning of the $1950 \mathrm{~s}$. When the large postwar age classes reached working age, they also raised the migration rates. In the early 1970 s and at the end of the decade migration weakened noticeably.

In the late 1970 s, as migration weakened, the structure of migration also changed. Previously, the direction of migration was clearly from the rural areas to the urban areas, but in the mid-1970s a distinct shift occurred when migration between urban areas became more frequent. Correspondingly, urban-to-rural migration also increased. The years with the highest unemployment also occurred at the end of the decade, and this restrained internal migration.

\section{Migration statistics}

In Finland, migration statistics are compiled by the Central Statistical Office. Statistics on migration have been compiled for already over 200 years. Migration statistics have mainly been composed of two sets of statistics: one is composed of internal migration statistics (migration between municipalities) and the other describes external migration. Prior to the 1920 s, migration statistics only contained data on the number of migrants. Statistics then began to be compiled which also told about the direction of migration and the distance it covered. In the $1950 \mathrm{~s}$, the informational contents of the migration statistics was supplemented, using a sample, with data including information about the migrants' age, marital status, industrial sector, occupation and occupational status. Starting in 1967, the data on age and marital status have been based on the total migrant population. Information on occupation, industrial sector and occupational status was based on population register data parish registers and the civil register then in existence - which were often incomplete or out-of-date. This, of course, weakened the reliability of the statistics.

In 1971, more reliable information on the socio-economic structure of the migrants was obtained for the first time for all of Finland. At this time, occupational and other data from the 1970 census were combined with the 1971 migration statistics data. ${ }^{4}$

${ }^{4}$ Myrskylä, Pekka: Muuttoliike 1950-1975, Tilastokeskus, Tutkimuksia Nro 40, Helsinki 1978. 
Statistics on migration within municipalities have been compiled since 1975 . Currently, these statistics only provide information on the number and age structure of the migrants.

\section{A survey of the reasons for migration}

The Finnish migration statistics provide a good basis for compiling various macro-level studies of migration. Individual-level studies have been limited only to the use of nation-wide information concerning occupation, industrial sector and education. No nation-wide statistics are available, however, on why people migrate, what their life circumstances are like when they migrate and how they adapt to their new surroundings. In order to remedy the situation, the Central Statistical Office made a survey of people who had migrated in Finland in 1977-78. The aim of this survey was, in addition to finding the demographic features of the migrants, to discover the reasons for migration, the life circumstances of the migrants before and after migration and to compare the characteristics of the migrants with persons who had not migrated.

The survey was composed of surveys of two samples:

(1) A sample of migrants, which was composed of persons over 15 years of age, who had changed residence from one municipality to another in 1977-78.

(2) A sample of persons who had not migrated in 1977-78 (the non-migrant sample). These persons formed the control group in this survey.

The interviews in the survey were performed by interviewers of the Central Statistical Office. In the migrant survey 1443 persons were interviewed, with the response rate at $86.8 \%$. In the control group 1103 persons were interviewed with a response rate of $84.8 \%$. The age structure of the control group was standardized to correspond to the migrant group's age structure. The aim of this procedure was to make these two samples comparable with each other according to age.

The migrant survey was primarily divided into the following sections. One section focused on demographic features and included, in addition to typical demographic characteristics, an examination of the (family) size and structure of the household. An effort was made to describe the background to migration by inquiring about events occurring prior to migration and about problems relating to migration itself. In the section describing the reasons for migration, the aim was to make an extensive examination of both the main reason for migration and other reasons leading up to the move. In addition, changes occurring in working conditions and in living conditions both before and after migration were examined. The survey also contained a section on the participation of the migrants in free-time and civic activities. The control group, the non-migrants, were given the same questions as the migrants - with the exception, of course, of questions pertaining to the reasons for migration. 


\section{Demographic features}

The migrants were young. Two-thirds of the migrants were under 35 . The control group, however, was not entirely comparable with the migrant sample in the older age groups, because for reasons of sample technique persons over 65 had to be omitted from the control group. Table 2 shows the age distribution of both interviewed samples.

$\mathrm{T} \mathrm{a} \mathrm{b} \mathrm{l} \mathrm{e} \mathrm{2.} \mathrm{The} \mathrm{age} \mathrm{structure} \mathrm{of} \mathrm{the} \mathrm{migrants} \mathrm{and} \mathrm{the} \mathrm{non-migrants.}$

\begin{tabular}{lcrcr}
\multicolumn{1}{c}{ Age } & Migrants & \multicolumn{3}{c}{ Non-migrants } \\
& Number & $\%$ & Number & $\%$ \\
$15-24$ & 499 & 35 & 453 & 41 \\
$25-34$ & 581 & 40 & 440 & 40 \\
$35-64$ & 313 & 22 & 210 & 19 \\
$65-$ & 50 & 3 & - & - \\
Total & 1443 & 100 & 1103 & 100
\end{tabular}

The marital status of the migrants before migration corresponds fully with the marital status of the non-migrants in the control group (Table 3). On the other hand, when examining marital status after migration, it differs quite a lot from the situation prior to migration. While slightly over one-half of the migrants were married before migration, after migration the proportion of migrants who were married had risen to $69 \%$. Getting married was one of the most common reasons leading to migration.

Table 3 also shows the size, number of children and family type of the households. Among the migrants, the size of the household had increased as a result of migration - one reason for this is that they got married, of course. Two- and three-person households are more common after migration than before. The size of the households in the non-migrant sample also differs clearly from the situation of the migrants both before and after migration. Among non-migrants, the proportion of small households is notably lower than in the migrant sample. The average household sizes calculated from the survey data for the migrants were 2.8 persons before migration and 3.1 persons after migration, in the non-migrant sample household size was noticeably higher than the above figures ( 3.4 persons). This is probably caused partly by the fact that there were relatively fewer one- and twoperson households in the non-migrant sample than in the migrant sample.

The proportion of one-child families among the migrants was $54 \%$, while the corresponding figure among the non-migrants was $46 \%$. Then again, there were relatively fewer two-child families among the migrants than among the nonmigrants. 
T a b l e 3. Marital status, household size, number of children and family type among migrants and non-migrants.

Marital status

Married

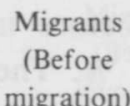

migration)

$\%$

54

46

100

\author{
Migrants \\ (After \\ migration)
}

$\%$

69

31

100
Nonmigrants

$\%$

55

45

100

Size of household

persons

$\begin{array}{rr}1 & 23 \\ 2 & 23 \\ 3 & 23 \\ 4 & 17 \\ 5- & 14 \\ \text { Total } & 100\end{array}$

Children

1
2
3
4

Total

Family type

Married; children

Married; no children

Lone parent

Person living alone

Total

Total

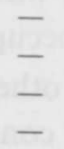

$\overline{-}$

$\begin{array}{rr}54 & 46 \\ 34 & 43 \\ 9 & 9 \\ 2 & 2 \\ 100 & 100\end{array}$

46

43

100

$\begin{array}{rrr}- & 45 & 37 \\ - & 24 & 17 \\ - & 6 & 3 \\ - & 25 & 43 \\ - & 100 & 100 \\ 1443 & 1443 & 1103\end{array}$

When examining the results according to family type, conclusions similar to the ones in the previous tables can be drawn. The largest migrant group was composed of married persons with children. Among the migrants $45 \%$ belonged to this group, while in the non-migrant control group the corresponding share was $37 \%$. Among the migrants $51 \%$ had children. This group was composed of persons who were married and had children and of lone parents, who totalled $6 \%$ of the migrant sample. In the non-migrant sample the number of persons living alone was relatively higher than in the migrant sample. Among the non-migrants only $40 \%$ had children, while the corresponding proportion of the migrants was over one-half. 


\section{Main activity, occupation and industrial sector}

Table 4 shows the main activity of the migrants and the non-migrants. Among the migrants $64 \%$ were employed before migration and after migration the employed proportion had risen to $71 \%$. The group »Others» includes, among others, persons caring for their own household; their share before migration was $86 \%$ of the total number in this group and after migration $93 \%$. Correspondingly, the proportion caring for their own household in the non-migrant control group was almost $94 \%$.

The type of activity among migrants and non-migrants did not differ greatly. In general, it can be said that the relative proportion of the unemployed among the migrants decreased as a result of migration. There is strong migration among students, of course, because after graduation people often move elsewhere to take a job. The proportion of students thus dropped, as a result of migration, from $12 \%$ to $6 \%$.

The occupational structure of the internal migrants differs most markedly from that of the non-migrants in the occupational group (0) which includes occupations in the fields of technology, natural science, the social sciences, the humanities and the arts, in occupations belonging to the industrial sphere $(4 / 6 / 7)$ and in agricultural occupations. One-third of the migrants belonged to occupational group 0 , while among the non-migrants the proportion was only $16 \%$. In this occupational group almost one-third of the migrants had occupations in health care. The mobility of persons working in agriculture, on the other hand, was relatively low, $5 \%$ of the migrants, while the proportion in the control group working in agriculture was $10 \%$.

Transitions in the respondent's activity, occupation and industrial sector were also examined in the survey. Among persons who were employed before migration $84 \%$ were still working after migration. It can be said that a move to another locality helped the unemployed gain employment, for $70 \%$ of the people who were unemployed before migrating were employed after migration. However, $17 \%$ of the unemployed were still out of a job after their move.

Changes in occupation which occurred with migration were most frequent when the former occupation was in agriculture or the service industries. When examining the data according to industrial sector, the greatest transfers over to other industrial sectors occurred in agriculture and in finance.

\section{Background to the actual occurrence of migration}

We attempted to shed light on the background to the actual migration with a few questions concerning matters which we assumed effected the success of the move. These questions were related to making the decision to migrate, prior knowledge about the new locality, how information about the new locality was obtained, whether the migrant had any acquaintances living in the new locality, who moved along with the migrant and problems relating to migration. 
$\mathrm{T}$ a b l e 4. Migrants and non-migrants according to main activity, occupation and industrial sector.

Migrants
(Before
migration)
$\%$

Main activity

Employed

Unemployed

Military service

Student

Work-disability

pension

Old-age pension

Other

Total

\section{Occupation}

Technical et al (0)

Administrative et al (1)

Commercial (2)

Agricultural (3)

Industrial/mining (4/6/7)

Transportation (5)

Social services $(8 / 9)$

Total

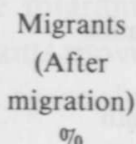

$\%$

Non-

migrants

$\%$

67

4

2

21

2

1

3

100

\section{Industrial sector ${ }^{6}$}

Agriculture

Industry/mining

Construction

Commerce

Transportation

Finance

Social services

Total

Total

5 International Standard Classification of Occupations (ISCO), 1969.

${ }^{6}$ International Standard Industrial Classification of All Economic Activities (ISIC), 1968.

Table 5 compares the time between the intention/decision to migrate and actual migration. The idea about migrating came to one-fifth of the migrants less than one month before the actual move, which, of course, demonstrates that the decision to migrate is sometimes made very quickly. The final decision to move was made by over one-half of the migrants less than one month before moving. 
$\mathrm{T}$ a $\mathrm{b} l \mathrm{e} 5$. The time passing between the intention/decision to migrate and actual migration (\%).

Time to actual migration in months

$$
\begin{array}{r}
\text { Less than } 1 \text { month } \\
1-6 \text { months } \\
6-12 \text { months } \\
\text { Over } \quad 12 \text { months }
\end{array}
$$

Total

$$
\begin{aligned}
& \text { Intention to } \\
& \text { migrate } \%
\end{aligned}
$$

$$
22
$$$$
38
$$

26

100
Decision to migrate $\%$

53
32
7
8
100

The majority of the migrants $(85 \%)$ migrated within six months after having made their final decision to migrate.

An attempt was made to estimate the familiarity of the locality the migrant moved to by asking how the migrant received information beforehand, was the locality already familiar to the migrant, and were there people living in the new locality who were already familiar to the migrant. In addition, the migrants were asked if reality corresponded to the information they had received.

In examining the advance information the migrants had obtained about the new locality, we find that the new municipality was in some way familiar to the majority of the migrants. Among the persons surveyed, $64 \%$ reported that the locality was already familiar to them, $13 \%$ had received information about local conditions from friends and relatives and $10 \%$ said that their main information came from visiting the new locality.

$\begin{array}{lr}\text { How information was obtained in advance } & \% \\ \text { Familiar locality } & 64 \\ \text { Visit to the locality } & 10 \\ \text { Friends/relatives } & 13 \\ \text { Other means } & 13 \\ & \end{array}$

When the migrants were asked whether the information they had received corresponded to reality, $75 \%$ replied that the obtained information corresponded to reality and only $2 \%$ reported that reality did not at all correspond to their preconception. Advance information most accurately corresponded to reality for people who were already familiar with the locality, who had visited the place or who had friends or relatives living there.

The migrants were also asked if they had any friends or relatives living in the locality they had moved to (Table 6). Among all migrants, $21 \%$ said that they had no friends or relatives living in the locality. Among persons who migrated to a rural area, one-fourth reported that they had no acquaintances in the new locality, while less than one-fifth of the persons moving to urban areas had no friends or relatives there. Among persons moving to urban areas, $63 \%$ had close relatives or other 
relatives living there. On the other hand, the corresponding proportion among migrants to rural areas was $53 \%$. If we add to these figures migrants with friends/acquaintances in the new locality, and compare migrants to urban areas with migrants to rural areas, we find that, currently, migrants moving to urban areas are moving to a more familiar locality, at least in respect to one's circle of friends, than migrants to rural areas.

$\mathrm{T}$ a b l e 6. Acquaintances living in the municipality of in-migration (\%).

Migrant sample

Close relatives ${ }^{1}$

Other relatives

Friends/acquaintances

No one

Total

spouse, children, parents, brothers and sisters
Municipality of arrival (\%)

$\begin{array}{crc}\begin{array}{c}\text { Entire } \\ \text { country }\end{array} & \begin{array}{c}\text { Urban } \\ \text { areas }\end{array} & \begin{array}{c}\text { Other } \\ \text { municipalities }\end{array} \\ 42 & 44 & 40 \\ 17 & 19 & 13 \\ 20 & 19 & 21 \\ 21 & 18 & 26 \\ 100 & 100 & 100 \\ 1443 & 893 & 550\end{array}$

It can be said, in general, that the problems (Table 7) people have at the time of migration are clearly related, in addition to work and housing, to one's livelihood and leaving one's friends behind. Finding suitable housing was very decidedly a problem for one-third of the migrants. One-fourth of the migrants felt that their livelihood and having to leave friends behind made it more difficult to move to another locality.

$\mathrm{T}$ a b l e 7. Problems related to migration (\%).

Problems related to migration

Effected migration

Greatly or Not at
to some
extent

Finding a job

Finding a job for a member of the family

Finding suitable housing

Livelihood

Children's schooling

Opportunities for further education

Leaving friends behind

Former hobbies

Unfamiliarity with services

Loneliness

$\begin{array}{rll}22 & 78 & 100 \\ 11 & 89 & 100 \\ 29 & 71 & 100 \\ 24 & 76 & 100 \\ 5 & 95 & 100 \\ 8 & 92 & 100 \\ 24 & 76 & 100 \\ 19 & 81 & 100 \\ 18 & 82 & 100 \\ 19 & 81 & 100\end{array}$

Total 
When comparing the two survey samples for permanence of living in the locality, the migrants are noticeably more willing to migrate elsewhere than persons who have not migrated within the past two years (Table 8). The question concerning the permanence of migration was stated in a way that enabled differentiation between persons who said they would remain in the locality and persons saying that they would live in the locality for a few years. Together these two groups were considered as composing a relatively uniform group characterized by long-term permanence of migration. The second group was composed of persons who said they would remain in the new locality for only a year or that they would move away immediately.

$\mathrm{T} \mathrm{a} \mathrm{ble} 8$. The permanence of living in - a locality among migrants and nonmigrants (\%).

Permanence in the locality

Migrants

Permanently

A few years

One year at the most

Will migrate immediately

Not able to answer

Total

Number

47
28
3
7
15
100
1443

1443
Non-migrants

62

21

4

2

11

100

1103

\section{The main reason for migrating}

The most important reason for migrating was unmistakably related to work (Table 9). For $44 \%$ of the migrants a reason concerning work was most important. Reasons related to housing were most important for $23 \%$ and changes in family relationships for $17 \%$ of the migrants. These three reasons comprise $84 \%$ of all the reasons for migration; the rest vary rather evenly between other reasons for migrating. Further education was the only one among the other reasons to rise to $5 \%$, while the other reasons remained below this figure.

Table 9 shows the most important reason for migration according to type of municipality of departure and of arrival. According to the type of municipality of departure, the distributions of the reasons for migration do not differ from each other very much. Only housing was more common (6 percentage points) as a reason for migration among persons migrating from urban areas than among those migrating from rural areas.

When examining reasons for migration according to the type of municipality of arrival, the distributions differ markedly from each other in regard to the reasons concerning work and housing. Among migrants to urban areas, reasons related to work were more common than among migrants moving to rural areas. In regard to reasons concerning housing, the differences between migrants to urban areas and migrants to rural areas were pronounced. While $19 \%$ of the persons migrating to urban areas said that housing was the main reason they were migrating, among per- 
$\mathrm{T}$ a b l e 9. The reasons for migration according to municipality of departure and of arrival $(\%)$.

\begin{tabular}{lrccrr} 
Reason for migration & \multicolumn{2}{c}{$\begin{array}{c}\text { Municipality of } \\
\text { departure }\end{array}$} & \multicolumn{2}{c}{$\begin{array}{c}\text { Municipality of } \\
\text { arrival }\end{array}$} & Total \\
& Urban & Other & Urban & Other \\
Work & 44 & 45 & 46 & 41 & 44 \\
Housing & 26 & 20 & 19 & 30 & 23 \\
Studies & 5 & 5 & 7 & 2 & 5 \\
Family & 16 & 18 & 16 & 17 & 17 \\
Services & 1 & 5 & 4 & 1 & 3 \\
Health & 3 & 3 & 4 & 3 & 3 \\
A desire for change & 1 & 1 & 1 & 1 & 1 \\
Other/not able to answer & 4 & 3 & 3 & 5 & 4 \\
Total & 100 & 100 & 100 & 100 & 100 \\
Number & 787 & 656 & 895 & 548 & 1443
\end{tabular}

sons moving to the countryside the corresponding proportion was already $30 \%$. There seem to be no significant differences regarding the other reasons for migration. Urban areas as municipalities of arrival attract more persons who migrate in order to continue their studies or because of the services available in the municipality. Then again, in examining the municipalities of departure, we find that services were more frequently a reason for migration among migrants from rural areas than among migrants from urban areas.

We will next examine the reasons that led to migration more closely.

\section{Work-related factors}

Forty-four percent of the migrants reported that the most important reason for their migrating were various reasons relating to work. In clarifying this question with various work-related factors, it turned out that the only reason one-fifth of the migrants had migrated was to change jobs in order to get more pay, better working hours or the like. Going to work after graduating was the reason almost one-fifth of the migrants migrated. Among the migrants $13 \%$ had to migrate to another locality because their workplace was being resituated; unemployment caused the migration of $12 \%$ of the migrants. For $15 \%$ the reason for migration was that a family member was getting a new job, while the transportation facilities to one's workplace was the reason $13 \%$ gave for migration.

Persons who mentioned getting a new job as the only reason they migrated were asked in more detail about reasons relating to this job change.

The decision to migrate seemed to be most affected by the attractiveness of the new job and the opportunities the new job provided for increasing the migrant's professional skills and work experience. Income, job terms, correspondence with one's schooling or uncertainty concerning the permanence of one's current job were not considered significant in affecting the decision to change one's job. 


\section{Housing-related factors}

Reasons relating to housing and the living environment were for $23 \%$ of the respondents the main reason they migrated. This was the second most common reason for migration. This survey concentrated on examining so-called long-distance migration. This apparently resulted in the slight underrepresentation of housing reasons, especially as the capital and its environs have been grouped together in the survey as an area of their own, and migration within this area has not been differentiated. Moving to new housing was significantly affected by the purchase of a dwelling of one's own, a change in the form of housing, acquiring a more appropriate dwelling or a more highly equipped dwelling. In addition, moving to more pleasant and quieter living surroundings significantly affected the decision to migrate. On the other hand, termination of one's housing lease, moving to a dwelling rented via one's workplace, housing costs, proximity to one's workplace and poor relations with the neighbors were not significant in causing the move to a new dwelling.

\section{Factors related to further education}

Various reasons related to further education were considered most important by $5 \%$ of all migrants. Almost all of these migrants said that their move was decisively affected by moving closer to where they were studying. This result seems very natural, for the major portion of the persons patricipating in the survey are so-called long-distance migrants. Here, especially the lack of educational opportunities in their former locality forced people to move elsewhere. Over one-half of the migrants considered the poor opportunities for further education existing in their former locality to have decisively led to their decision to migrate.

\section{Factors related to family relationships}

For $17 \%$ of the migrants changes in family relationships were the reason for migration. These reasons composed the third most common reason for migration. Together with reasons related to changing one's job and to housing these three reasons form $84 \%$ of all reasons for migration.

The largest group of changes in family relationships clearly was formed by those getting married. This group also included persons who moved in order to start cohabiting. Among the migrants $72 \%$ considered getting married as having affected migration either greatly or to some extent.

Other reasons related to changes in family relationships were not very significant in causing migration. Divorce or separation led to migration for $17 \%$ of the migrants. The effect of other changes in family relationships on migration was slight. 


\section{Other reasons given}

Other reasons cited as the most important for migration all remained under $5 \%$. This group included reasons related to transportation, services and leisure-time activities which composed $3 \%$ of all reasons for migration (services). The effect of health reasons on migration was about equal in size. These groups were already so small numerically that in interpreting them we can only speak of general tendencies.

Among reasons related to services, only the out-of-the-way location of the former locality and its poor transportation facilities were considered by most migrants to have been the most important reason for migration. Other servicerelated reasons were not emphasized as much, although over $60 \%$ of the migrants felt that they had some or much impact on the decision to migrate. Among reasons concerning health, better health services can be distinguished as clearly affecting migration; almost half of the migrants in this group reported that reasons concerning health were decisive for migration. This response distribution also clearly reflects the age structure of these migrants, for the majority of these migrants were older than those in the other groups of reasons for migration.

\section{The direction of migration according to the reason for migration}

In the 1970 s, migration had noticeably slowed down and clear changes had occurred in the direction of migration. While migration flows in the 1960 s were clearly directed from rural areas to urban areas, in the mid-1970s the migration flows changed clearly. A special feature of the migration of the years included in the survey is the relative growth of migration from one urban area to another compared to that of previous years.

As shown in Table 10,62\% of the migrants moved to urban areas. The former locality of one-half of these migrants was an urban area. One out of three migrants moved from one urban area to another.

The reasons for migration also differ quite a lot according to the direction migration took. Migrants to urban areas cited reasons relating to work, schooling, and services more frequently than migrants to rural areas. On the other hand, housingrelated reasons are clearly emphasized among migrants to rural areas - however, the proportion of migrants to rural areas was less than one-half of all migrants who migrated for housing-related reasons.

When we examine the reasons for migration according to the direction of migration we find that the proportion of work reasons as reasons for migration was highest. Among persons migrating only in rural areas or only in urban areas, over one-half gave work as the most important reason for migration. Only among urbanto-rural migrants were housing-related reasons more frequent than other reasons for migration. This can partly be explained by many people moving to the countryside for the very reason of housing, even though they continue to work in the city. 
$\mathrm{T}$ a $\mathrm{b} \mathrm{l}$ e 10 . The reasons for migration according to the direction of migration $(\%)$.

\begin{tabular}{|c|c|c|c|c|c|c|}
\hline $\begin{array}{l}\text { Reason for } \\
\text { migration }\end{array}$ & $\begin{array}{l}\text { Urban-to- } \\
\text { rural }\end{array}$ & $\begin{array}{l}\text { Rural-to- } \\
\text { rural }\end{array}$ & $\begin{array}{l}\text { Urban-to- } \\
\text { urban }\end{array}$ & $\begin{array}{c}\text { Rural-to- } \\
\text { urban }\end{array}$ & Total & Number \\
\hline Work & 18 & 17 & 36 & 29 & 100 & 636 \\
\hline Housing & 37 & 12 & 24 & 27 & 100 & 335 \\
\hline Studies & 12 & 1 & 41 & 46 & 100 & 75 \\
\hline Family & 26 & 13 & 26 & 35 & 100 & 239 \\
\hline Services & 10 & 10 & 13 & 67 & 100 & 40 \\
\hline Health & 29 & 8 & 25 & 38 & 100 & 48 \\
\hline $\begin{array}{l}\text { Other/Not a } \\
\text { to answer }\end{array}$ & 24 & 20 & 36 & 20 & 100 & 70 \\
\hline Total & 24 & 14 & 31 & 31 & 100 & 1443 \\
\hline Number & 345 & 203 & 442 & 453 & 1443 & \\
\hline Work & 33 & 54 & 51 & 41 & 44 & 636 \\
\hline Housing & 36 & 19 & 18 & 20 & 23 & 335 \\
\hline Studies & 3 & 0 & 7 & 8 & 5 & 75 \\
\hline Family & 18 & 16 & 14 & 18 & 17 & 239 \\
\hline Services & 1 & 2 & 1 & 6 & 3 & 40 \\
\hline Health & 4 & 2 & 3 & 4 & 3 & 48 \\
\hline $\begin{array}{l}\text { Other/Not a } \\
\text { to answer }\end{array}$ & 5 & 7 & 6 & 3 & 5 & 70 \\
\hline Total & 100 & 100 & 100 & 100 & 100 & 1443 \\
\hline Number & 345 & 203 & 442 & 453 & 1443 & \\
\hline
\end{tabular}

If we want to summarize the migrants according to the direction of migration, we can say that most migrants move to urban areas mainly because of a job. However, migration to rural areas, mainly in order to find housing, has begun to vie with migration to urban areas. One-fourth of the migrants are urban-to-rural migrants, and for one-third of these migrants housing was the main reason they migrated.

\section{Main activity}

Before migration migrants who were employed totalled $73 \%$, and after their move the total had increased to $76 \%$. In this section, we have examined the main activity before migration and reasons for migration. The reasons for migration included here are only the ones most frequently mentioned, that is work, housing, studies and changes in family relationships. The other reasons for migration have been grouped together mainly because these groups are so small.

An examination of the main activity of the migrants according to their reasons for migration shows that the migrants are clearly concentrated in the economically active population (Table 11), where the proportion of the employed together with that of the unemployed is clearly the largest. To some extent there are differences 
between the various reasons for migration: for example, for many migrants who moved mainly because of studies, the main activity before migration had also been studies. In addition, in the group »other reasons» the largest proportion of migrants were work-disabled $(27 \%)$.

$\mathrm{T}$ a b l e 11. Main activity before migration and the reason for migration $(\%)$.

\begin{tabular}{|c|c|c|c|c|c|c|c|c|}
\hline \multirow{2}{*}{$\begin{array}{l}\text { Reason for } \\
\text { migration }\end{array}$} & \multicolumn{6}{|c|}{ Main activity before migration ( $\%)$} & \multirow[t]{2}{*}{ Total } & \multirow[t]{2}{*}{ Number } \\
\hline & $\begin{array}{c}\text { Em- } \\
\text { ployed }\end{array}$ & $\begin{array}{l}\text { Unem- } \\
\text { ployed }\end{array}$ & $\begin{array}{l}\text { Mili- } \\
\text { tary } \\
\text { ser- } \\
\text { vice }\end{array}$ & $\begin{array}{l}\text { Stu- } \\
\text { dent }\end{array}$ & $\begin{array}{l}\text { Work- } \\
\text { dis- } \\
\text { abled }\end{array}$ & $\begin{array}{l}\text { Pension- } \\
\text { ers and } \\
\text { others }\end{array}$ & & \\
\hline Work & 63 & 12 & 1 & 15 & 2 & 7 & 100 & 636 \\
\hline Housing & 68 & 6 & 1 & 6 & 11 & 8 & 100 & 335 \\
\hline Studies & 52 & 9 & 4 & 31 & 3 & 1 & 100 & 75 \\
\hline Family & 68 & 10 & 1 & 13 & 5 & 3 & 100 & 239 \\
\hline Other & 55 & 4 & - & 6 & 27 & 8 & 100 & 158 \\
\hline Total & 64 & 9 & 1 & 12 & 7 & 7 & 100 & 1443 \\
\hline Work & 44 & 58 & 46 & 52 & 12 & 47 & 44 & 636 \\
\hline Housing & 25 & 14 & 18 & 12 & 34 & 30 & 23 & 335 \\
\hline Studies & 4 & 5 & 27 & 13 & 2 & 1 & 5 & 75 \\
\hline Family & 18 & 18 & 9 & 18 & 11 & 8 & 17 & 239 \\
\hline Other & 9 & 5 & - & 5 & 41 & 14 & 11 & 158 \\
\hline Total & 100 & 100 & 100 & 100 & 100 & 100 & 100 & \\
\hline Number & 922 & 132 & 11 & 179 & 105 & 94 & 1443 & 1443 \\
\hline
\end{tabular}

When examining the different "main activity» groups according to the reason for migration, we find that the distribution of the employed according to migration reason follows almost the same distribution as the entire migrant sample. On the other hand, in main activity groups the distribution according to the reason for migration already differs more markedly. Over one-half $(58 \%)$ of the unemployed felt that the reason for migration was related to work. Most of the students are completing their vocational training and have moved to another locality to take a job. Among the students, $52 \%$ reported that their most important reasons for migrating were related to work.

In all the main activity groups work, housing and changes in family relationships are emphasized as reasons for migration. Among the work-disabled/persons about to retire, reasons mainly concerning health were the second most common reasons for migration, with their proportion at $41 \%$.

\section{Occupation}

Table 12 examined the reasons for migration according to occupation. In all groups of reasons for migration, persons who had no occupation (were economical- 
ly inactive) were the largest migrant group. On the other hand, when examining the survey data according to occupation, in all reasons for migration the migrants were concentrated clearly into two occupational groups: industrial occupations and occupations in the technical-scientific-societal sector. Of these two, industrial occupations are the most common occupations in all reasons for migration, except for reasons associated with work.

On the other hand, when examining different occupational groups according to the reason for migration, the frequency of work-related reasons is apparent in every occupational group. Among practitioners of technical-scientific-societal occupations and administrative and commercial occupations the proportion of work reasons was one-half of their reasons for migration, while the smallest proportion (33 \%) of work-related reasons was found among industrial employees. In all occupational groups the distribution of reasons for migration conforms to almost the same distribution as in the migrant sample as a whole. Work-related reasons are most frequently represented, second are housing-related reasons and the third most common cause of migration are changes in family relationships.

$\mathrm{T}$ a b l e 12 . Occupation and the reason for migration (\%).

\begin{tabular}{|c|c|c|c|c|c|c|c|c|c|c|}
\hline Reason for & & & Occupat & on befor & migrati & n $(\%)$ & & & Total & Numbe \\
\hline migration & $\begin{array}{l}\text { Tech- } \\
\text { nical, } \\
\text { social } \\
\text { sciences } \\
\text { et al }\end{array}$ & $\begin{array}{l}\text { Ad- } \\
\text { min- } \\
\text { istra- } \\
\text { tive }\end{array}$ & $\begin{array}{c}\text { Com- } \\
\text { mer- } \\
\text { cial }\end{array}$ & $\begin{array}{l}\text { Agri- } \\
\text { cul- } \\
\text { tural }\end{array}$ & $\begin{array}{l}\text { Indus- } \\
\text { try } \\
\text { and } \\
\text { min- } \\
\text { ing }\end{array}$ & $\begin{array}{c}\text { Trans- } \\
\text { porta- } \\
\text { tion }\end{array}$ & $\begin{array}{l}\text { Ser- } \\
\text { vic- } \\
\text { es*) }^{*}\end{array}$ & Other & & \\
\hline Work & 23 & 10 & 5 & 3 & 12 & 3 & 7 & 37 & 100 & 636 \\
\hline Housing & 19 & 9 & 5 & 2 & 22 & 4 & 7 & 32 & 100 & 335 \\
\hline Studies & 15 & 4 & 3 & 2 & 17 & 3 & 8 & 48 & 100 & 75 \\
\hline Family & 15 & 8 & 5 & 5 & 23 & 4 & 8 & 32 & 100 & 239 \\
\hline Other & 13 & 6 & 1 & 5 & 16 & 5 & 9 & 45 & 100 & 158 \\
\hline Total & 19 & 9 & 4 & 3 & 18 & 4 & 7 & 36 & 100 & 1443 \\
\hline Work & 52 & 50 & 50 & 43 & 33 & 38 & 41 & 44 & 44 & 636 \\
\hline Housing & 23 & 24 & 25 & 12 & 30 & 27 & 23 & 20 & 23 & 335 \\
\hline Studies & 4 & 2 & 3 & 4 & 5 & 4 & 6 & 7 & 5 & 75 \\
\hline Family & 13 & 16 & 19 & 25 & 22 & 18 & 18 & 15 & 17 & 239 \\
\hline Other & 8 & 8 & 3 & 16 & 10 & 13 & 13 & 14 & 11 & 158 \\
\hline Total & 100 & 100 & 100 & 100 & 100 & 100 & 100 & 100 & 100 & \\
\hline Number & 275 & 127 & 60 & 49 & 240 & 55 & 107 & 530 & 1443 & 1443 \\
\hline
\end{tabular}

\section{Industrial sector}

Over one-third of the migrants ( $36 \%$ ) did not belong to the economically active population before they migrated (Table 13). According to industrial sector, one- 
fifth of the migrants ( $22 \%$ ) were employed before migration in social services and $18 \%$ in industry. These two industrial sectors were clearly the largest. The proportion of all migrants employed in the commercial sector was $10 \%$. The above proportions also include persons who are not economically active.

When examining reasons for migration according to industrial sector, workrelated reasons are decidedly the largest group. In commerce, finance and social services work reasons made up almost one-half. In all industrial sectors the distribution of reasons for migration confirms in the main to the distribution obtained for the entire migrant sample. Agriculture and transportation are the only sectors where the distribution of reasons for migration differs more clearly, but on the other hand, there were so few migrants in these industrial sectors that more far-reaching conclusions cannot be made.

$\mathrm{T}$ a b l e 13 . Industrial sector and the reason for migration (\%).

\begin{tabular}{|c|c|c|c|c|c|c|c|c|c|c|}
\hline \multirow{2}{*}{$\begin{array}{l}\text { Reason } \\
\text { for } \\
\text { migration }\end{array}$} & \multicolumn{8}{|c|}{ Industrial sector before migration (\%) } & \multirow[t]{2}{*}{ Total } & \multirow[t]{2}{*}{ Number } \\
\hline & $\begin{array}{l}\text { Agri- } \\
\text { cul- } \\
\text { ture }\end{array}$ & $\begin{array}{l}\text { Indus- } \\
\text { try and } \\
\text { mining }\end{array}$ & $\begin{array}{l}\text { Con- } \\
\text { struc- } \\
\text { tion }\end{array}$ & $\begin{array}{l}\text { Com- } \\
\text { merce }\end{array}$ & $\begin{array}{l}\text { Trans- } \\
\text { porta- } \\
\text { tion }\end{array}$ & $\begin{array}{l}\text { Fin- } \\
\text { ance }\end{array}$ & $\begin{array}{l}\text { Social } \\
\text { ser- } \\
\text { vices }\end{array}$ & $\begin{array}{c}\text { In- } \\
\text { active }\end{array}$ & & \\
\hline Work & 3 & 16 & 3 & 10 & 3 & 3 & 25 & 37 & 100 & 636 \\
\hline Housing & 2 & 22 & 6 & 8 & 6 & 2 & 22 & 32 & 100 & 335 \\
\hline Studies & 1 & 13 & 4 & 11 & - & 1 & 22 & 48 & 100 & 75 \\
\hline Family & 6 & 21 & 4 & 10 & 5 & 4 & 18 & 32 & 100 & 239 \\
\hline Other & 4 & 16 & 6 & 8 & 2 & 3 & 16 & 45 & 100 & 158 \\
\hline Total & 3 & 18 & 4 & 10 & 4 & 3 & 22 & 36 & 100 & 1443 \\
\hline Work & 42 & 39 & 31 & 47 & 38 & 48 & 49 & 44 & 44 & 636 \\
\hline Housing & 12 & 28 & 32 & 20 & 35 & 19 & 24 & 20 & 23 & 335 \\
\hline Studies & 2 & 4 & 5 & 6 & - & 2 & 5 & 7 & 5 & 75 \\
\hline Family & 29 & 19 & 18 & 18 & 22 & 21 & 14 & 15 & 17 & 239 \\
\hline Other & 15 & 10 & 14 & 9 & 5 & 10 & 8 & 14 & 11 & 158 \\
\hline Total & 100 & 100 & 100 & 100 & 100 & 100 & 100 & 100 & 100 & \\
\hline Number & 48 & 263 & 62 & 136 & 55 & 42 & 316 & 521 & 1443 & 1443 \\
\hline
\end{tabular}

\section{Education}

Over one-half $(52 \%)$ of the migrants had a secondary level education, less than one-third $(31 \%)$ had a primary level education and the rest $(17 \%)$ had a higher level education (Table 14).

The educational level varied somewhat according to the reason for migration. There were more highly educated people among persons who cited work as the reason for migrating than among the other groups of migration reasons.

In examining reasons for migration according to educational level, we find that work-related reasons are clearly the most frequent at all levels of education and their significance grows the higher we go in the educational hierarchy. When $33 \%$ of the 
migrants with a primary level education said that work reasons were the most important cause of migration, at the highest educational level the corresponding proportion had risen to $59 \%$. The proportion migrating for housing reasons was greater among persons with a primary level education than in other educational groups. The significance of changes in one's family relationships as a cause of migration decreased the higher educational level: one-fifth of the migrants with a primary level education moved for family reasons while among those with a higher level of education the proportion was only $9 \%$.

$\mathrm{T}$ a b l e 14. Education and the reason for migration (\%).

$\begin{array}{lccccr}\begin{array}{l}\text { Reason for } \\ \text { migration }\end{array} & \begin{array}{c}\text { Level of education }(\%) \\ \text { Primary } \\ \text { level }\end{array} & \begin{array}{c}\text { Secondary } \\ \text { level }\end{array} & \begin{array}{c}\text { Higher } \\ \text { level }\end{array} & \text { Total } & \text { Number } \\ \text { Work } & 24 & 53 & 23 & 100 & 636 \\ \text { Housing } & 39 & 47 & 14 & 100 & 335 \\ \text { Studies } & 5 & 73 & 22 & 100 & 75 \\ \text { Family relationships } & 37 & 53 & 10 & 100 & 239 \\ \text { Other } & 47 & 43 & 10 & 100 & 158 \\ \text { Total } & 31 & 52 & 17 & 100 & 1443 \\ & & & & & \\ \text { Work } & 33 & 45 & 59 & 44 & 636 \\ \text { Housing } & 29 & 21 & 19 & 23 & 335 \\ \text { Studies } & 1 & 8 & 7 & 5 & 75 \\ \text { Family relationships } & 20 & 17 & 9 & 17 & 239 \\ \text { Other } & 17 & 9 & 6 & 11 & 158 \\ \text { Total } & 100 & 100 & 100 & 100 & 1443 \\ \text { Number } & 449 & 746 & 248 & 1443 & \end{array}$

\section{Summary}

In the following we will attempt to summarize what characterizes the Finnish migrant according to the results of this survey.

The migrant is most likely under 35 , married, migrating with his or her family to another municipality. This is perhaps the second or third move within a period of a few years.

Regarding education, the majority of the migrants have completed vocational training and the reason for migration for the majority is getting a new job, getting new housing or getting married.

The majority of the migrants are members of the economically active population, their occupation is in the field of technology or the social sciences and over one-third of the migrants belong both before and after migration to the industrial sector of social services. The largest groups of individual occupations among the migrants were occupations in the health care sector and skilled male industrial workers. 
The decision to migrate is made relatively rapidly - for most in less than six months. The migrant often knows the locality he is migrating to relatively well or he has obtained sufficient information about the locality. Most migrants already have relatives or other acquaintances living in the municipality of arrival.

The difficulties relating to migration are mainly apparent as searching for housing and as a general concern about one's livelihood. 